\title{
Legal Pluralism and Tenure Security: Exploring the Relationship between Statutory and Customary Land Tenure in Zambia
}

\author{
Anthony Mushinge ${ }^{1}$, Sharon Mulenga ${ }^{2}$ \\ ${ }^{1}$ Chair of Land Management and Land Tenure, Technical University of Munich, Munich, Germany \\ ${ }^{2}$ Government Valuation Department, Ministry of Local Government and Housing, Lusaka, Zambia
}

Correspondence: Anthony Mushinge, Chair of Land Management and Land Tenure, Technical University of Munich, Arcisstrasse 21, D-80333, Munich, Germany.

Received: January 25, 2016

doi:10.11114/ijsss.v4i3.1331
Accepted: February 5, $2016 \quad$ Available online: February 11, 2016

URL: http://dx.doi.org/10.11114/ijsss.v4i3.1331

\begin{abstract}
The purpose of the research is to: 1) investigate the interpretation of the sections in the Lands Act of 1995 that provide for the statutory recognition on one hand, and conversion of customary land, on the other; and 2) discuss the effects of the said sections on customary landholders. Methodologically, qualitative methods (largely in-depth interviews) were used to conclude that governments in sub-Sahara Africa are the architects of tenure insecurity because they (knowingly or otherwise) enact laws that are contradictory or conflicting in nature. In the case of Zambia, there are contradicting sections within the Lands Act 1995 where, while one section provides for the conversion of customary land, the other provides for statutory recognition of the same traditional tenure. This therefore casts a shadow of confusion regarding the meaning of "statutory recognition" in that in practice "legality", by way of holding private title deed, always takes precedence over "social legitimacy". The implication of this is tenure insecurity and an associated avalanche of evictions, elite capture, sub-division and enclosures of common pool resources, land grabs, and land conflicts. We recommend that, guided by research, concerned governments should consider emulating other countries like Tanzania and Botswana, which have enacted "bespoke" land laws that are specifically meant for state land, and other land laws specifically for customary land.
\end{abstract}

Keywords: Zambia, state land, customary land, customary land recognition, customary land conversion

\section{Introduction}

Land is arguably one of the most fundamental natural resources of any country (Mabogunje, 1990; Agbosu, 2000). Chikhwenda (2002) and Mabikke (2014) argue that this is because the resource forms the basis for existence as all forms of production, food, shelter and human sustenance rely on the presence of land. Furthermore, land provides welfare support; is a source of prestige, a symbol of spiritual status, personal dignity and identity (Leonard and Longbottom, 2000). With this in mind, it can be argued that the manner in which the resource is administered can contribute to a country's sustainable development agenda (Deininger, 2003). However, this can potentially be hampered by the fact that about $90 \%$ of land in many developing countries is still under customary ownership (Deininger, 2003). For this reason, many observers, policy makers and development agencies, like the World Bank, vigorously campaign for the transformation of customary tenure systems into the widely eulogized system of private property under statutory tenure (Bruce and Migot-Adholla, 1995). This is in order to activate what de Soto (2000) calls the dead capital in the customary tenure systems. The drive towards what is regarded as modernisation of customary tenure has been anchored on the various sources of dissatisfaction with the customary tenure institutions. This includes the fact that customary tenure is said to be insecure, backward, antiquated, primitive accumulation and it does not promote land/credit markets (Shivji, 2006; Deininger, 2003).

However, the agenda to transform the customary tenure systems into private property tenure seems to be undermined by the usually contradictory nature of the provisions of state land laws in many developing countries. In most sub-Sahara African countries, for example, it is not uncommon to find pieces of legislation that provide for privatisation of customary land while at the same time enabling the 'statutory recognition and continuation' of the customary tenure systems (Ng'ombe and Keivan, 2013). This contradictory legislation is highlighted by anecdotal evidence, which suggests that although its existence is 'statutorily recognised', customary tenure has in practice continued to be 
expropriated by public officials on grounds that the customary tenure system lacks security as the landholders do not own title deeds (de Soto, 2000). Numerous court orders have been issued in favour of individuals who may have acquired title to their land after having very recently converted customary land into private property (Lobulu, 1998). The result, in many cases, has led to customary land owners being evicted from their land once the land is successfully converted to private property (Brown, 2005). This perfectly mirrors the situation in Zambia where the provisions to both statutorily recognise and convert customary land have had mixed outcomes.

The land tenure system in Zambia is twofold: state and customary land. In line with the provisions of legal pluralism, where state and customary law co-exist as two legal systems, state land is administered by central government using state law while customary land is administered by traditional rulers using local customs (Ng'ombe and Keivani, 2013). The land laws previously in place upon acquiring independence were vestiges of colonial rule, perpetuating colonial systems of race-based land categorization (Knight, 2010). Such laws were neither adequate for addressing modern landrelated transactions, particularly the growing land markets in urban and peri-urban areas; nor relevant to the complex and multiple ways that rural Zambians use, share and transact land (ibid). Over the past four decades, successive Zambian governments have made land reforms aimed at increasing national development and prosperity by empowering people with land ownership and attracting investment with the promise of greater tenure security (GRZ, 1995). However, Zambian land lawmakers have faced and continue to confront a complex situation, administering land under two land tenure systems operating under different land laws. State land is governed by statutory law whereas customary land is governed by customary legal paradigms. Being statutorily recognised, the decisions and rules established under customary tenure systems are recognised as legally valid and binding by law. The two systems do not operate in complete isolation from one another but a fissure exists between them. The end result are two legal systems functioning side by side, blending and mixing, and increasingly clashing at places of interaction. Against this background, this paper uses Zambia's dual tenure system to examine the nature of the interface between legality and social legitimacy in land ownership, particularly insofar as this relates to provisions in the law that recognise customary land whilst at the same time providing for the conversion of customary land to private property. In so doing, we attempt to answer key questions, including: 1) What is the interpretation, relationship between, and consequences of sections 7(1) and 8(1) in the Lands Act of 1995 - the former provides for the recognition of customary land tenure systems while the latter provides for the conversion of customary land to private property 2) Why, despite the provision of its 'recognition' in the Lands Act, has customary land continued to be expropriated by private land owners with support from public officials, leading to customary land owners being evicted from their land? The paper draws on international literature, personal experience and research in Zambia to find answers to these questions.

\section{The (Legal) Case for Customary Land Tenure}

Customary land rights can be discussed in the context of human rights, in general, and self-determination, in particular (United Nations, 2008). These are provided by, among others, the International Labour Organization's Convention number 169 of 1989 (ILO, 1989), African Charter on Human and Peoples Rights (Organisation of African Unity, 1981), and the United Nations Declaration on the Rights of Indigenous Peoples (the UN Declaration) (United Nations, 2008). Article 13 of the ILO Convention, for instance, implores governments to respect the cultures and spiritual values of the indigenous peoples, including their relationship with their land, particularly the manner in which they own it - i.e. customary ownership. Article 14 emphasizes the need for governments to identify, recognize and protect the traditional forms of land ownership of the indigenous peoples, i.e. customary land rights. The Convention also makes a provision for the need for governments to consult indigenous peoples in matters related to the allocation of their lands, particularly if such allocations are to be made to outsiders (Article 17(2)). Furthermore, the Convention prevents outsiders from taking advantage of the autochthons' customs and/or indigenous peoples' ignorance in terms of how they can access land.

Article 14 of the African Charter on Human and Peoples Rights provides that the right to property shall be guaranteed (Organisation of African Unity, 1981). The scope of Article 14 of the African Charter does not only apply to individual property but also apply to collective/communal rights to land which are essentially grounded on cultural norms. The Charter places upon governments' party to the Charter an obligation to protect the customary people's rights to property by putting in place appropriate pieces of legislation. In this regard, by expropriating customary lands in order to promote private investment, states are abrogating human rights of marginalised communities.

Other than the ILO Convention and African Charter on Human and Peoples Rights, the UN Declaration, and the Draft American Declaration on the Rights of Indigenous Peoples were developed to further reaffirm the need for governments of the UN member states to uphold and legitimise concerns/rights of the indigenous peoples to land and self-determination (United Nations, 2008; Carino, 2006; MacKay, 2004). Article 26 of the UN Declaration, for instance, states that: 
Indigenous peoples have the right to the lands, territories and resources which they have traditionally owned, occupied or otherwise used or acquired. Indigenous peoples have the right to own, use, develop and control the lands, territories and resources that they possess by reason of traditional ownership or other traditional occupation or use, as well as those which they have otherwise acquired. States shall give legal recognition and protection to these lands, territories and resources. Such recognition shall be conducted with due respect to the customs, traditions and land tenure systems of the indigenous peoples concerned (United Nations, 2008: 10, emphasis added).

It is evident from the preceding text that interest in the welfare of the indigenous peoples, including their access to land, is growing all over the world. Durning (1992) argues that this is, in part, because of the growing awareness from the international community of the existence of a direct link between rural peoples and sustainable economic development. The indigenous peoples' way of life is said to be very ideal for driving forward the sustainability agenda. According to Durning (1992: 6 - 7), this can be attributed to a number of factors:

First, indigenous peoples are the sole guardians of vast, little-disturbed habitats that modern society depend on more than they may realise - to regulate water cycles, maintain the stability of the climate, and provide valuable plants, animals, and genes. Their homelands may harbour more endangered plant and animal species than all the world's nature reserves. Second, they possess, in their ecological knowledge, an asset of incalculable value: a map to the biological diversity of the earth on which all life depends. Encoded in indigenous languages, customs, and practices may be as much understanding of nature as is stored in the libraries of modern science.

According to Durning (1992) and Carino (2006), the indigenous people's desire and ability to observe sustainability is due to two main factors. The first is that these people have a long-standing view that they are not the owners of land and other natural resources. Rather, they consider themselves as mere custodians or stewards of natural resources and biodiversity, thereby self-imposing some degree of restriction in the way they exploit natural resources. Secondly, ritual restrictions also play an important role of a watchdog against over-exploitation of natural resources. For example, there are certain forests in Africa where it is considered an offence by the traditional leadership to cut trees because it is believed that such forests are a source of rain (Peters, 2002, 1992).

Notwithstanding the foregoing factors, indigenous peoples from across the world feel that their efforts in driving the sustainability agenda are not being recognised by the campaigners of sustainable development. In order to correct this misrepresentation, over 300 indigenes from across the world gathered at the International Indigenous Peoples Summit on Sustainable Development in Kimberly, South Africa, August $20-23$, 2002, at which they reaffirmed their commitment to human and environmental sustainability (Carino, 2006). Their concerns and commitments were well summarised in what became known as the Kimberly Declaration (2002) that was signed by all the indigenous leaders in attendance, and submitted to the World Summit on Sustainable Development held in Johannesburg, 26 August -4 September 2002 (the Rio+10). In their submission, the indigenes stated that:

We, the Indigenous Peoples, ... are the original peoples tied to the land by our umbilical cords and the dust of our ancestors... Our special places are sacred and demand the highest respect ... As peoples, we reaffirm our rights to self-determination and to own, control and manage our ancestral lands and territories, waters and other resources. Our lands and territories are at the core of our existence - we are the land and the land is us; we have a distinct spiritual and material relationship with our lands and territories and they are inextricably linked to our survival and to the preservation and further development of our knowledge systems and cultures, conservation and sustainable use of biodiversity and ecosystem management (Kimberly Declaration, 2002: 1).

Inspite of indigenous peoples' desire and ability to contribute to conservation and sustainable use of biodiversity, Durning (1992: 4) shows that their rights are constantly "endangered by onrushing forces of the outside world" as governments, in the name of development and/or improvements in local living standards, seek to integrate such rights into capitalist models of holding land. Lobulu (1998), for instance, narrates how in 1987 the Prime Minister, through the "Extinction of Customary Land Rights Order" in Tanzania, aimed at wiping out all traditional tenure system in that country. In particular, the Order stated that "All customary land rights within the areas specified in the Schedule to this Order which areas are in Arusha Region, are hereby extinguished; [And] where any customary land right is extinguished in accordance with paragraph 2, the land shall rest in the District Council which has jurisdiction over the area where the land is situated and that District Council may distribute that land in the way it deems fit" (ibid). Hence, despite the existence of legal provisions on the customary land rights highlighted in section 1, indigenous peoples' rights to land in Zambia and many other developing countries still risk extinction. Subsequently, some commentators have argued that forcing capitalist models of holding land for development or progress on tribal peoples does not necessarily make them happier or healthier (Survival International, 2007). For instance, in his tour of the Amazon in 2008, Bruce Parry discovered that according to the 'uncontacted tribes' of the Amazon, progress or development was 
the major cause of disease and hence a potential cause of their extinction (Note 1). The most important factor for the well-being of the Amazon people was whether their rights to land were guaranteed, respected and protected (ibid).

While this section highlights international recognition for customary land tenure, the instruments referred to merely grant social legitimacy to the need to secure all forms of customary land rights. The legislative instruments required to effect and enforce the security of customary land tenure entail the integration of socially legitimised instruments into statutory land tenure systems. In the following section, we highlight how the development of land policy from the pre-colonial era to the current post-colonial land reform era has attempted to or failed to integrate socially legitimised instruments into statutory land tenure systems in Zambia.

\section{Land Tenure/Policy in Zambia: A Historical Perspective}

The history of land policy development in Zambia and how it affects customary land rights is threefold: pre-colonial, colonial and post-colonial.

\subsection{Pre-colonial Era}

Prior to the coming in of the white settler community in 1890, all land in the country was held jointly by families or by a chief or chieftainess on behalf of the community in accordance with the community's respective customary laws (Mudenda, 2007, p.351). The resource was considered to be a free gift from God and hence the individuals in the land-owning group had the right to use the land but not to sell it (GRZ, 2002, p.3). Nonetheless, the people were allowed to transfer rights in land for consideration, or as gifts subject to the local conditions and customs, while interest in land could also be inherited in accordance with the respective customary laws (ibid: 3 ). For example, as early as the 1800s in the Barotse Kingdom (now Western Province), open access resources were co-owned by several villages, who also collectively designated areas into wildlife sanctuaries and forest reserves. Systems were also collectively put in place to manage use-rights through the sharing of benefits (e.g. harvest and off-takes) and the establishment of storage facilities for emergency use (Mbewe et al. 2005). Customary laws were also recognised as well established user-group rules, sacred controls and civic controls that were clearly understood and accepted by community members. By-laws were also associated with penal codes and sanctions instituted to effect land use by stipulating what to do and what not to do (Kayambazinthu et al. 2003). Examples of customary rights to land included rights to occupy, administer or cultivate land; or rights to hunt in an area (Berry 1989).

Customary laws were therefore recognised as rights that were negotiated at community level, with rules agreed to in relation to these rights. These laws generally formed the primary system that governed interactions between traditional landowners, which made them important social forces (Yung \& Belsky 2007). However, several examples show lack of continuity in the effectiveness of customary laws due to the influx of new institutions created during the colonial and post-colonial periods. During these periods, some functions and responsibilities of the traditional leadership, which are key to effecting customary laws, were either taken up by the new institutions or found to be irrelevant and done away with (Kayambazinthu et al. 2003).

\subsection{Colonial Era}

The traditional tenure systems that existed before 1890 were affected by the arrival of the first European settlers. The advent of colonialism saw the development of policies and government legislation that provided a legal framework for land use and management, which weakened traditional systems of land management and inadvertently undermined traditional tenure systems and decision-making processes (Mbewe et al. 2005). Through this legal framework, structures of power were altered to allow colonial authorities appoint their own candidates to positions of authority within them. New overarching structures of government were established for central control over powers of coercion over rights to access, use and manage land (Berry 1989).

The colonial legislative framework saw the division of the country into three categories of land, namely: crown land, reserves and trust land. The Europeans introduced the system of holding land under certificate of title and consequently led to their settlement on crown land, which was the most fertile and rich in minerals (Mudenda, 2007, p.367). To this effect, the Lands and Deeds Registry Act - Chapter 185 was enacted in 1944 to provide for: (1) the registration of documents; (2) the issuance of provisional certificates of title and certificates of title; and, (3) the transfer and transmission of registered land and for incidental matters so as to ensure that all interests in the land and other immovable properties were systematically registered (GRZ, 2006).

Prior to registration, crown land was surveyed. This land was administered under English Law, in which leasehold and freehold tenure systems were practiced and guaranteed (Mudenda, 2007, p.367). The registration of crown land enabled white settlers to use title deeds as collateral in borrowing money to develop their land. This enabled them to develop their land more economically than reserve land. Ownership of crown land by indigenous people was not permitted, except with permission to stay either as licensees in compounds or as house servants for the white settlers (Mutale, 
2004). The indigenous people were expected to always return to their homelands (reserve lands). Crown land comprised 6 percent $(45,180$ square kilometres) of the total land mass. The remaining 94 percent $(707,820$ square kilometres) comprised trust and reserve land. Trust land was set-aside for public purposes and was unregistered. On the other hand, reserve land was set aside for indigenous people who traced their ancestry in particular areas within the country (Mudenda, 2007, p.365).

\subsection{Post Independence Era}

After gaining independence from Britain in 1964, Northern Rhodesia became Zambia. Zambia, like most independent countries in southern Africa after the colonial era, changed its property rights systems. This change of property rights systems was similar to the colonial era and further weakened customary laws, since they were associated with clans and other groups considered to be problematic for the newly independent countries (McCay 1996). In order to manage these problematic customary systems, statutory land regulations cut across all forms of land categories. These statutory regulations followed socialist ideologies under the Zambian Government at the attainment of independence, which was largely constituted by the United National Independence Party (UNIP), and led to the re-categorisation of crown land as state land, while reserve and trust lands were combined into customary land. The UNIP government made additional major land reforms in 1975 and 1985. Further reforms were made by the successive Movement for Multiparty Democracy (MMD) government in the 1990's (Brown, 2005). The following sections highlight how these reforms affected customary land rights that existed prior to the post-independence era.

\subsubsection{Land Reforms of 1975}

The cornerstone of the land reforms of 1975 was the "Watershed Speech" made by the then president of the Republic of Zambia, Dr. Kenneth Kaunda to the UNIP National Council on $30^{\text {th }}$ June 1975 . Under the section dealing with land reform, the speech read:

The political rule of UNIP on land is that this is a gift from God and cannot be sold and especially be made the subject of speculation by human exploiters (Kaunda, 1975).

This presidential decree on land matters led to the development of government legislation that weakened traditional tenure systems - the Land (Conversion of Titles) Act number 20 of 1975, chapter 289 of the laws of Zambia. The Act introduced a land nationalisation programme by vesting all land in Zambia in the President, to be held by him in perpetuity for and on behalf of the people of Zambia (Mudenda, 2007, p.380). By vesting all land in the President, this legislative framework inadvertently undermined traditional tenure systems and decision-making processes. In addition, freehold tenure was abolished and substituted with the renewable statutory leaseholds for a maximum period of 99 years, effective $1^{\text {st }}$ July 1975 (ibid). All sales of land per se (except improvements on the land) were prohibited (Mudenda, 2007, p.382). All undeveloped land was acquired by the central or local government, as were most forms of rented property (ibid). In exercise of his powers, the President was empowered to fix the maximum amount received, recovered or secured in any land transaction, provided that in fixing such amount, no regard was to be taken of the value of the land, only the developments on the land (Mudenda, 2007, p.382). The granting, alienation or transfer of land to non-Zambians was also prohibited (ibid).

\subsubsection{Land reforms of 1985}

The Land (Conversion of Titles) Act of 1975 was amended in 1985. This was done to extend ownership rights to non-Zambians through the granting, alienation or transfer of land. This could be done if: (1) a person had been approved as an investor in accordance with the law relating to the promotion of investment in Zambia; (2) the interests or rights in land were being inherited upon death or were being transferred under a right of survivorship or by other operation of law; (3) the interests or the rights in question arose out of a lease, sublease or under lease for a period not exceeding 5 years or a tenancy agreement; (4) it was a non-profit making organization or institution; and (5) the president of Zambia had given his consent in writing under his hand (Mudenda, 2007, p.385).

\subsubsection{The post-1991 reforms under the MMD government}

In 1991, the country experienced a major change in terms of its political and economic governance. The term of office of the UNIP government came to an end, and the new government under the Movement for Multiparty Democracy (MMD) came into power. Thus, the country changed from a one-party state with socialist ideologies to a multi-party state with a liberalized market economy. This economic change was associated with privatization of land ownership through a Land Bill of 1993. However, this Bill was controversial in the sense that it was drafted by the top leadership without the consultation of the key stakeholders such as traditional leaders, the general public and civil society organisations. The privatisation of land was hence seen as a government move that would disadvantage the majority of poor people, who had no capacity to purchase land or access it through the laborious and expensive land delivery system of the government (Mudenda, 2007, p.406). Therefore, the traditional leaders, civil society and other key 
stakeholders rejected the Bill, arguing that once turned into law it would disadvantage the majority poor people and undermine the authority of traditional leaders with regard to administration of customary land (ibid). However, the Bill was passed into law in 1995 and is still in effect as the 'Lands Act of 1995'. This Act replaced the Land (Conversion of Titles) Act of 1975 and Land (Conversion of Titles) Amendment Act of 1985.

The Lands Act of 1995 provides for: (1) the continuation of vesting land in the president in perpetuity for and on behalf of the people of Zambia; (2) the recognition of an economic value to land. Thus, from 1995 both land and improvements on land can be monetised and sold; (3) the establishment of a land development fund for rural development; and (4) the establishment of the Lands Tribunal for speedy resolution of land disputes.

In relation to customary land, the 1995 Lands Act has made mention of customary tenure in two sections where it makes simultaneous provisions for: 1) the recognition and continuation of customary land; and 2) for the conversion of customary tenure to statutory tenure. Section 7 (1) provides that:

Every piece of land in a customary area which immediately before the commencement of the Lands Act was vested in or held by any person under customary tenure shall continue to be so held and recognised.

This proviso in the Act appears to offer legal protection to occupants of customary land, and thus entails that customary tenure is a legally recognised system of land ownership in Zambia. On the other hand, section 8(1) provides that:

Notwithstanding the recognition and continuation of customary tenure, any person who holds land under customary tenure may convert it into a leasehold tenure not exceeding ninety-nine years on application.

Primarily this proviso was aimed at increasing land under state control and opening more land to both local and foreign investment. But these provisions of the Lands Act have been received with mixed feelings around the country, with some commentators arguing that the provision to convert customary land into leaseholds is the very source of the widespread eviction threats/displacements, elite capture, socio-economic exclusion, intra-community conflicts, community disquiet, sub-divisions and enclosures of common pool resources (Brown, 2005). These impacts are regarded as embodiments of social division in the Zambian context (Peters, 1992) as they further weaken traditional land tenure systems by bringing more land under statutory regulations. In a recent research (Malambo, 2013), of all customary land that was converted to leaseholds in Chibombo District in Central Province in April and July 2013, only $2 \%$ were converted by applicants from within rural communities while $98 \%$ were converted by outsider applicants.

\section{Methodology}

The research was primarily qualitative in nature and adopted a case study approach, where the Shimukunami chiefdom in Lufwanyama District was studied (figure 1). The Shimukunami chiefdom, in particular, and Lufwanyama District, in general, were chosen as an ideal case that would provide empirical data on customary land rights based on the views of indigenous stakeholders, including traditional rulers and the local communities. Other stakeholders that were identified as key informants included legal and lands officers at the Ministry of Lands; a research officer at the High Court (Lusaka); local authority representatives at Lufwanyama District Council; and a representative from the Zambia Land Alliance (a consortium of non-governmental organisations with a stake in land matters). The main method of data collection used with the stakeholders was in-depth face-to-face interviews. Secondary data were also gathered through an analysis of international literature as well as judgments on land-related cases obtained from within Africa. Another set of interviews were conducted in North-western Province, which included the provincial lands officer at the Ministry of Lands (provincial office); two officers at the Department of Agriculture in Solwezi; and two representatives of the Mumena Royal Establishment in Mumena chiefdom, Solwezi. Fieldwork was conducted between October and December 2013 and September and November, 2015. 


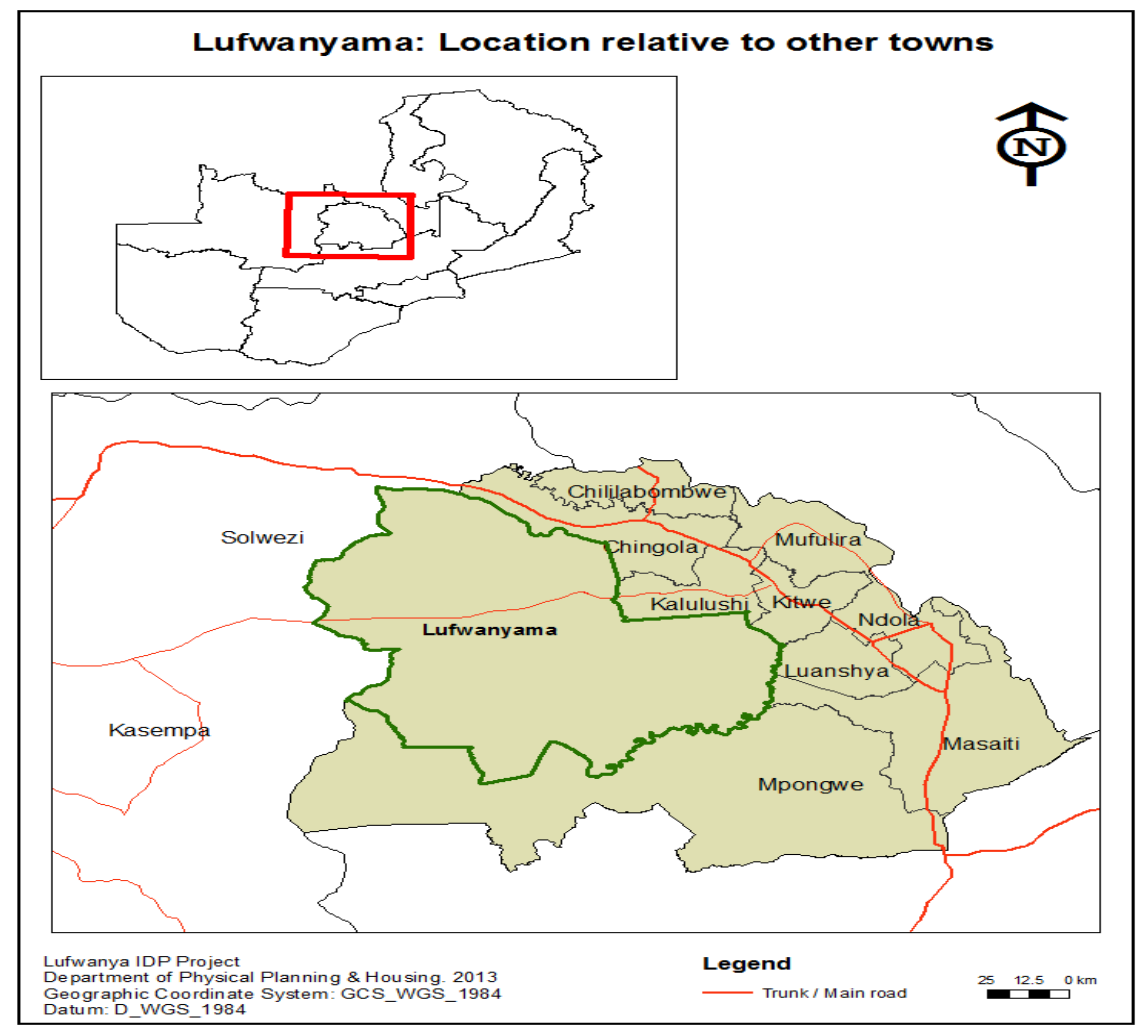

Figure 1. Map showing location of study area (Source: modified from Lufwanyama Department of Physical Planning and Housing, 2013)

Focus group discussions were conducted with indigenous local communities as customary landholders in the Shimukunami chiefdom in order to determine the consistency of empirical data from other key stakeholders, thereby also enhancing data validation. This method of data collection was considered most appropriate since the indigenous landholders were more open to discuss in groups than as individuals. This mode of communication was also found to be the norm in most rural areas of Zambia. Furthermore, focus group discussions were found to be more vibrant and facilitated interjection from other members of the group.

In terms of sampling, the study adopted non-probability sampling because the population size was not entirely known, making it difficult to determine individual probability. Under the non-probability sampling techniques, purposive sampling and convenience sampling were chosen. The former was used to select stakeholders that were known beforehand that they had a role to play in land matters (e.g. chiefs, lands officers, and relevant land administration agencies), while the latter was used to select rural communities.

\section{Results and Discussion}

\subsection{Interpretation of sections 7 and 8 of the Lands Act}

Section 7(1) of Zambia's Lands Act provides for the recognition and continuation of customary land tenure. When asked about the interpretation of such a provision, the legal officer at the Ministry of Lands (MOL) responded that the section merely assures customary landholders that they would not be deprived of the rights they held before the Lands Act was enacted in 1995. The section simply takes into account the 'welfare' of the people in a customary area and not necessarily providing security of tenure through ownership titles (I1 - Legal Officer). It was found that although the Act 'recognizes' customary land, it does not give effect to registration of its ownership. In terms of section 8 (1), which provides for the conversion of customary tenure to leaseholds, respondents noted that the section enables people who held land under customary tenure without title, to obtain title on their land (I1 - Legal Officer). Similar sentiments were raised by respondent 15 (a researcher at the High Court in Lusaka - the respondent was also a lawyer). When asked whether and to what extent, if at all, sections 7(1) and 8(1) contradicted/conflicted one another, the respondent stated in the email correspondence that:

The Act envisages that the person that will convert customary tenure to leasehold tenure is one who first must have acquired the rights under the customary tenure. The Act has to that effect provided a control by way of procedure of conversion under Section 4. Any person who fails to follow the procedure will be sanctioned and 
the title to land deemed null and void. Thus, when a person is victimized by the other who purports to have obtained title to it without meeting the procedural requirements, the victim has liberty to invoke Section 4 'protection'. Any conflict? In my view, there is no conflict. Only that lack of enlightenment by most customary tenure land holders is costing their well vested rights even in the face of the shield in section 4 (personal email communication, 9 May 2014)..

The same question was also asked to respondent 16 (lawyer and former Commissioner of Lands at the Ministry of Lands in Lusaka). His sentiments were similar to those of respondent 15 above, arguing that there was nothing wrong with the provisions in the Lands Act of 1995. Even the two sections under investigations were okay. The respondent went on to say that while the provisions of the sections were in good faith, the problem was with the implementation vis-a-vis following the necessary land allocation procedure as top government officials were sometimes found to disregard the formal procedure.

While concerns for individual title ownership are addressed through the conversion of customary tenure to leasehold tenure, there is no provision for the converse. This clearly indicates that the statutory tenure system is held in higher esteem than the customary land tenure system. It was noted that legislation is silent on the registration of customary ownership rights and only provides for conversion to private ownership rights, implying that only the elite and notable locals can own land that is secure and not subject to conflicts. Chieftainess Shimukunami highlighted in interview that some of the problems surrounding the conversion of customary land into leaseholds were as a result of the fact that while the Lands Act authorises the President to allocate land to an investor, this cannot be done without consulting the local chief. However, consultations with traditional authorities are limited to surface land rights since the Act exempts minerals from coming under the control of the chiefs. The foregoing interpretation of the legislation implies that while surface rights belong to the chiefs, the underground/mining rights belong to government, which further suggests that the latter seem to preside over the former. The implication of this, according to the Chieftainess, is that the government may at any time issue mining licenses to investors without taking into consideration the rights of the local people.

Our findings show that section 8(1) (on conversion) takes precedence over section 7(1) (on recognition), making statutory tenure being of greater importance over customary tenure because the latter does not provide security of tenure through ownership titles. This was evidenced by 12 (Zambia Land Alliance), who revealed that the two sections clearly contradict each other because "it does not make sense for the same Act to recognise customary tenure while at the same time making provisions that seek to wipe out the same tenure system it seeks to recognise". The implication of this is customary tenure insecurity and an associated avalanche of evictions, elite capture, sub-division and enclosures of common pool resources, land grabs, and land conflicts.

\subsection{Recognition of Customary Tenure}

On the issue of 'recognition' in the Lands Act, I1 (Legal Officer, MOL) noted clearly that although customary tenure is a legally recognised form of land tenure, it does not offer security of tenure, leading to widespread evictions from customary land. I3 (Provincial Lands Officer, MOL) further illustrates this understanding by stating that "recognition of customary land is more or less super fiction". The respondent indicated that the recognition mentioned in the Lands Act "[was] not there in reality because it does not provide entitlement." He further substantiated his interpretation by giving an example of a case in Kalumbila (an area in North-western Province where a mine is proposed to be opened) where 518,000 square kilometres of land has been converted, leaving many families without land while the promised compensation programme is not only slow but the amounts are considered inadequate by the beneficiaries.

It can therefore be seen that in Zambia the recognition of customary land without any evidence of security of land ownership is thus artificial and has led to the many eviction cases in the country (Brown, 2005) as one can only be protected if they convert their land to obtain title. In essence, therefore, ownership of customary land cannot be proved, let alone defended, by occupants of customary tenure when evicted. As revealed by I4 (Department of Agriculture, Solwezi), the recognition provided for in the Lands Act is weak and has also been poorly implemented because a title deed is considered of greater importance. The issue of social legitimacy of customary tenure seems to be overlooked in Zambia as legality is seen to be taking centre stage. On the other hand, it was also revealed in discussions with chiefs' subjects that sometimes the chiefs are to blame when it comes to the conversion of customary land as provided by the Lands Act. Although the Act provides that when making the decision to allocate land, especially to an outsider, the chief must consult their subjects, some respondents argued that chiefs in most cases do not consult their subjects especially if the investor is of a high profile as transactions of that nature can often involve exchange of big sums of money as a "token of appreciation" for land. This finding is in agreement with Brown's (2005) findings where he states that some chiefs in Zambia have assumed the positions of business tycoons with closer ties to outsiders. When presenting a number of cases in Zambia where traditional rulers have had problems dealing with their subjects regarding allocation of customary land to high profile private investors,for example, Brown (2005: 95 - 96) reports that in 1996 there were only 3 investors with 
titles to land in Chieftainess Chiawa's area on the outskirts of Lower Zambezi National Park. By 1999, 19 more tour operators had acquired titles on land converted from customary tenure. Lodges were built on river-side locations where scenery and wildlife viewing were at their best. The investors (white Zambians and foreigners) fenced off their land and could conduct routine patrols. The investors did not recognize previously-held land use rights. It is reported that due to her pro-development stance Chieftainess Chiawa had had a litany of run-ins with her subjects. The chieftainess is an outspoken proponent of outside investment in her area. At one time she even appeared in a television advertisement promoting the virtues of the 1995 Lands Act, using tourist and agricultural developments in her chiefdom as her backdrop. But the number of leaseholds the Chieftainess has sanctioned - and her positive attitude towards private foreign investors - have undermined her local support. She is accused of having a hidden agenda and failing to listen to her subjects.

In another case, a more volatile encounter between chief and subjects ensued in Mbeza on the Kafue flats - a very fertile floodplain along the Kafue River. The chief of the area, Bright Nalubamba, had been pushing for a section of the floodplain to be developed as a rice farm. With the backing of Italian investors, the chief hoped to transform the area into a private commercial farming block - the Mbeza Integrated Project. Although the investors claimed that no one was going to be displaced, the local Ila people resisted the project on the basis that they would lose grazing land. Accordingly, the residents formed the Indigenous People's Rights Committee (IPRC) to challenge the chief's clandestine motive. Despite the antagonism, police deployment, court cases, threats and confrontations between the chief and IPRC, the development-intended project was put on hold (ibid). Furthermore, Mpundu (2006), in her Panos Features article, reports of a case in Kabanje, a small village near Mazabuka town (130km south of Lusaka) where a land dispute erupted between villagers and a private sugar-manufacturing firm. Over 100 families and their 17,000 cattle were facing an eviction threat as Zambia Sugar Plc was claiming ownership of the land (locally known as Farm 1343) occupied by the villagers for over 50 years. The reason advanced by the firm was that it needed to expand its operations in order to meet the growing European demand for sugar. Despite the potential advantages of the expansion to the local community (e.g. creation of jobs - which the residents themselves actually acknowledged), the local communities, backed by their traditional ruler, vehemently refused to move, arguing that:

We know no other home than this. Our parents were born here. We were born here and our children [were] born here. There is no other home we know. Where are we going to move to?...Our Malende (ancestral shrines) and the graves of our families are all here. How do we vacate and leave the remains of our forefathers in strange custody? (ibid: online).

In an effort to register their displeasure at relocating, the villagers even went to the extent of burning sugar cane fields, while some of their ring leaders, mostly headmen, were arrested and taken to court for disobeying a Lusaka High Court eviction order.

\section{Conclusion and Recommendation(s)}

What seems to emerge from this research is that while the two sections in contention seem to be not contradictory to the lawyers, they are confusing and actually contradictory to an ordinary person, including civil servants like the Provincial Lands Officer who said the recognition of customary tenure as provided by s. 7(1) of the Lands Act 1995 is 'super fiction'. This is cause for concern because the fact that the ambiguity of the said sections are felt by senior government officers in the Ministry of Lands presents a precarious situation where interpreting the Act becomes challenged due to lack of understanding by those officers like the Lands Officers who interpret/implement the national laws. Furthermore, the research reveals that due to the widespread none-following of correct land allocation procedures in many land allocation agencies, although the Lands Act of 1995 ostensibly recognises customary tenure, it does not provide tenure security in that it does not protect this kind of tenure by way of entitlement. Strictly speaking, state recognition without legal protection as provided for in the African Charter is, as one respondent told us in our survey, regarded as "super fiction". A conclusion can therefore be drawn to say that intrinsically the Lands Act has not recognised customary tenure. It is also clear from the findings that the Lands Act holds customary tenure in lower esteem than statutory tenure because it has not provided for its registration or any form of entitlement as is the case with other countries like Botswana and Tanzania where customary tenure is not only legally recognised (as in Zambia) but also legally protected - meaning that the customary land law there is equivalent to the state codified law (Knight, 2010). Customary tenure is therefore perceived to be insecure by most people in the country as those with title deeds can easily prove ownership in a court of law and thus protect themselves against evictions. The Zambian land law can therefore be regarded as biased because statutory tenure seems to be taking precedence over customary tenure thereby causing uncertainties and ambiguities in the customary land sector. These findings therefore question the extent to which (if at all) the international law on the rights of indigenous people with respect to property rights/land (like the ILO Convention 169 and African Charter) are respected/domesticated in Zambia.

In view of our findings, we recommend that the Zambian government should show commitment to strengthening 
customary land rights and administration by emulating their best practice counterparts in sub-Saharan Africa like Tanzania and Botswana. Both these countries have properly recognised customary tenure by way of enacting separate customary land laws - the Village Land Act 1999 and the Tribal Land Act 1968, respectively. Since these laws are held to be bespoke, they define more specifically the land rights of people under customary tenure and solely deal with customary tenure whilst allowing also space for customs.

\section{Acknowledgements}

The authors acknowledge the assistance provided by: Legal and Lands Officers at the Ministry of Lands (Lusaka); Research Officer at the High Court (Lusaka); Local Authority Representatives at Lufwanyama District Council; Chieftainess Shimukunami; Zambia Land Alliance; and customary landholders in Shimukunami chiefdom in Lufwanyama District.

\section{References}

Agbosu, L. K. (2000). Land law in Ghana: Contradiction between Anglo-American and customary conceptions of tenure and practices. Land Tenure Center working paper, 33, University of Wisconsin, Madison.

Brown, T. (2005). Contestation, confusion and corruption: market based Land Reform in Zambia. In S. Evers, M. Spierenburg, and H. Wels (eds) Competing Jurisdictions: Settling land claims in Africa (pp. 79-107). Leiden: Brill Academic Publishers,.

Bruce, W. J., \& Migot-Adholla, S. (1995). When should property rights be formalised? Issues in the phasing of property system reforms. In D. Umali-Deininger and C. Maguire (eds.) Agriculture in liberalizing economies: Changing roles for governments, Proceedings of the fourteenth agriculture sector symposium, 1994, World Bank, Washington, D.C.

Carino, J. K. (2006).Ancestral land, food sovereignty and the right to self-determination: Indigenous people's perspectives on agrarian reform. Contribution to the Civil Society Issue Paper "Land, territory and dignity", for the International Conference on Agrarian Reform and Rural Development (ICARRD), 7 - 10 March 2006, Porto Alegre, Brazil.

Chikhwenda, E. J. W. (2002). Transactive land tenure system in the face of globalisation in Malawi. Paper presented at the 9th IASCP (International Association for the Study of Common Property) Biennial Conference: The commons in the age of globalisation 17 - 21 June 2002, Victoria, Zimbabwe.

Crook, R., Affou, S., Hammond, D., Vanga, A. F., \& Owusu-Yeboah, M. (2007). The law, legal institutions and the protection of land rights in Ghana and Cote d'Ivoire: Developing a more effective and equitable system. IDS Research Report 58. Institute of Development Studies, University of Sussex, Brighton.

de Soto, H. (2000). The mystery of capital: Why capitalism triumphs in the West and fails everywhere else. Basic Books, New York.

Deininger, K. (2003). Land policies for growth and poverty reduction. World Bank, Washington, D.C.

Durning, A. T. (1992). Guardians of the land: Indigenous peoples and the health of the earth. Worldwatch Institute, Washington, D.C.

FAO (2010). Statutory Recognition of Customay Tenure: . (Food Agriculture Organisation)FAO .

GRZ (2002). The Draft Land Policy (2002). Government Printers, Lusaka.

GRZ (2006). Draft Land Administration and Management Policy. Ministry of Lands, Lusaka.

ILO (International Labour Organisation) (1989). Convention Concerning Indigenous and Tribal Peoples in Independent Countries, No. 169. ILO, Geneva.

Kaunda, K.D. (1975). The Watershed Speech to the National Council of the United National Independence Party. Mulungushi Hall. 30 June - 3 July, 1975.

Kimberley Declaration (2002). Kimberley Declaration. International indigenous peoples summit on sustainable development, 20 - 23 August 2002, Kimberly, South Africa.

Knight, S. R. (2010). Statutory recognition of customary land rights in Africa: An investigation into best practices for lawmaking and implementation. Food and Agriculture Organisation of the United Nations, Rome.

Leonard, R., \& Longbottom, J. (2000). Land tenure lexicon: A glossary of terms from English and French speaking West Africa. International Institute for Environment and Development (IIED), London.

Lobulu, B. (1998). Dispossession and land tenure in Tanzania: what hope from the courts? CSQ, 22(4). Retrieved 
January.https://www.culturalsurvival.org/publications/cultural-survival-quarterly/224-winter-1998-uprooted-dispos session-africa.

Mabikke, S. (2014). Improving Land and Water Governance in Uganda: The Role of Institutions in Secure Land and Water Rights in Lake Victoria Basin (Unpublished doctoral dissertation). Technical University of Munich, Munich, Germany

Mabogunje, A. L. (1990). Perspective on urban land and urban management in sub-Saharan Africa. World Bank, Washington, DC.

Machina, H. (2005). Land Policy and Administration in Zambia. A paper presented to the MS-Zambia Annual Workshops, Lake Kariba Inns, Siavonga, Zambia, 1-5th February 2005.

MacKay, F. (2004). Indigenous peoples' rights to lands, territories and resources: Selected international and domestic legal considerations". Land Reform: Land Settlement and Cooperatives 2004/1: pp. 80 - 95.

Malambo, A. H. (2013). Land administration in Zambia since 1991: History, opportunities and challenges. Global Advanced Research Journal of History, Political Science \& International Relations, 2(4), 53 - 66.

Mpundu, M. (2006). Zambia village takes on the sugar barons. Panos Features, 3 April 2006.

Mudenda, S. F. (2007). Land Law in Zambia. Cases and Materials.UNZA Press, Lusaka.

Mutale, E. (2004). The management of urban development in Zambia. Ashgate, Aldershot.

Ng'ombe, A., \& Keivan, R. (2013). Customary Land Reform to Facilitate Private Investment in Zambia: Achievements, Potentials and Limitations. Urban Forum, 24 (1), 33-48.

Organisation of African Unity (1981). African Charter on Human and Peoples Rights. Addis Ababa, Ethiopia.

Peters, P. E. (2002). Bewitching land: The role of land disputes in converting kin to strangers and in class formation in Malawi. Journal of Southern African Studies, 28(1), 155-178.

- (1992). Manoeuvres and debates in the interpretation of land rights in Botswana. Africa, 62(3), 413 - 434.

Shivji, I. G. (2006). Lawyers in neoliberalism: Authority's professional supplicants or society's amateurish conscience?" Valedictory lecture, 16 July 2006, University of Dar es Salaam, Tanzania.

Survival International (2007). Progress can kill: How imposed development destroys the health of tribal peoples. Survival International, London.

United Nations (2008). Declaration on the rights of indigenous peoples. Resolution 61/295 of 13 September 2007, United Nations, Geneva.

\section{Notes}

Note 1. British Broadcasting Corporation (BBC) 2008 TV series of the exploration of the Amazon and its tribes.

\section{(cc) $\mathrm{Br}$}

This work is licensed under a Creative Commons Attribution 3.0 License. 